\title{
SOLUTION OF PROBLEM OF SUPPLYING THE POPULATION WITH QUALITY DRINKING WATER
}

\author{
Goncharuk Vladyslav \\ A.V. Dumansky Institute of Colloid and Water Chemistry of National Academy of Sciences of Ukraine, 42, Vernadsky blvd., 03680, \\ Kyiv-142, Ukraine, tel.(+380 44) 4240196,fax(+380 44)4238224, e-mail: honch@iccwc.kiev.ua

\begin{abstract}
The reasons of poor quality of the drinking water, submitted to consumers have been analyzed. The new concept of supplying the population with high quality drinking water is offered. Qualitative and safe for health drinking water is produced on site of its consumption (using the installations for well-room type). The ways for solving of legislative, organization and technical problems required for realization of the proposed concept are considered.
\end{abstract}

Keywords: high quality drinking water, supplying of the population, concept.

\section{Introduction}

The problem of supplying the population with quality drinking water, safe for human health, is especially socially significant since its solution directly affects the degree of ecological and epidemiological safety of many regions. The question on the quality of drinking water has long ago stepped over national frontiers and has taken a global nature. The priority in its statement belongs, first of all, to native scientists: to Academician of the Academy of Sciences of the USSR S.V.Iakovlev and to Academician of the Academy of Sciences of the UkrSSR L.A.Kulskij.

In numerous works they recognized that a society had come to understanding of the importance of the problem of drinking water quality. The hygienic congress on drinking water in Brussels in 1853 accepted the first standard regulating quality of drinking water on 9 parameters which could be authentically determined in conditions of laboratories of water supply plants and rendered obvious influence on the human health. Such parameters were normalized on organoleptic parameters of water quality and on its scale-forming properties. Further, aroused the necessity of bringing to conformity the technologies of preparation of drinking water to quality of water in a source of water supply at a legislative level.

\section{The new concept of supplying the population with high quality drinking water}

Real realization of such approach is DSTU 4808:2007 standard [1]. Alongside with basic researches in this area at its development the special attention was given to achievements in practice of water-preparation. DSTU 4808:2007 standard is the first normative document in Ukraine from a series of the standards guaranteeing the supplying of the population by high-quality drinking water. It incorporates essentially new approaches [2] of supplying of the population by high-quality drinking water with use as a source of water supply waters with a various degree of impurities. They consist in, that consumption of water for the economic - household purposes and for drink (including meal preparation) is precisely differentiated, and include:

- Creation and putting into practice of the uniform interconnected system of State Standards on drinking water, safe for human health, namely four standards: on drinking water supply sources; tap water of sanitary-and-hygienic purposes; drinking water of the increased quality; the packed water.

- The providing of the population with high-quality and safe for health drinking water in volumes, sufficient for satisfaction of physiological needs of the person, is carried out on a place of its production using installations of wellroom type. Such drinking water is obtained mainly from underground waters protected against anthropogenic influence or from tap water.

- Water of the centralized water supply is produced mainly for sanitary-and-hygienic needs that almost in 100 times exceed physiological person need. In this case it is obtained mainly from the water of surface sources.

- For settlements and villages where the centralized water supply is absent, installations of well-room type are used for production of drinking water of the high quality from surface and underground water sources.

- In regions where there are no sources of low mineralized waters, drinking water of the improved quality could be received from sea and mineralized waters by their desalination.

Practical implementation of this concept is taking into account that specifically developed technical measures should be based on the complex knowledge about the factors affecting the quality of drinking water. Among these factors the following should be taken as the first priority: inequality in regional supply of quality sources of water which results in the necessity for finding alternative water sources; a strong tendency for the worsening of water quality in traditional sources of drinking water supply; secondary contamination of water at water treatment facilities and in the water system; the necessity of rapid response to the quality of the initial water at the time of obtaining drinking water; new possibilities of obtaining drinking water due to the use of modern technologies; the impact of the conditions of water supply on its 
quality and, certainly, the state of the water system. At the same time, one of the main areas of work aimed at supply of the population with water meet to high standards is the use for assessing the quality of the final products of new approaches making it possible to credibly evaluate water suitability for its consumption. Introduction of such techniques to the standards provides not only a possibility to monitor the consumer's quality of the water being used, but to create incentives for the introduction of technical solutions securing nontoxicity of drinking water and its physiological full value.

The basic sources of drinking water production are surface and underground waters. The majority of surface waters are characterized by a high level of biological and chemical pollution, in particular, surface-active substances, mineral oil, phenols etc.

In Ukraine centralized water supply is realized mainly due to use surface water sources (about 70\%), the most of which are strongly polluted. About $35 \%$ of wastewaters enter water bodies without treatment and the untreated ones that are not in compliance with sanitary standards-39\%. This is a reason for a stable tendency for deterioration of the ecological state of water bodies both in terms of sanitary-chemical and microbiological indicators. [3,4]. The research carried out as early as in 1994-1997 [5] demonstrated that each 4-5th samples of water from the water bodies, which formally refer to categories I and II does not meet hygienic standards by sanitary-chemical indicators and every 3-4th sample does not meet microbiological indicators. Organic compounds, suspended substances, oil products, phenols, synthetic SAS, heavy metals, etc. have remained priority pollutants for many years. Among disease pathogens salmonellas, eteroviruses, etc. are determined in water most often [5]. Monitoring results of the quality of the surface waters in the sites of water intakes of Ukraine's drinking water systems are evidence of the fact that the concentration of priority harmful chemical substances approaches the maximum admissible concentration (MAC) and in some cases even exceed them. Under such situation the possibility of obtaining quality drinking water become complicated since the existing water treatment systems effectively do not secure a barrier function as for technogenic chemical substances-they enter drinking water by transit. In 1994-1997 all surface water sources of Ukraine by the level of pollution approached the 3rd quality class and in terms of the international classification-class 4-5 [5]. And in this case the composition of the treatment facilities and technology of water treatment up to now have remained invariable.

The striking example of such a situation was detection in water supply systems of micromycetes (Fig.1).
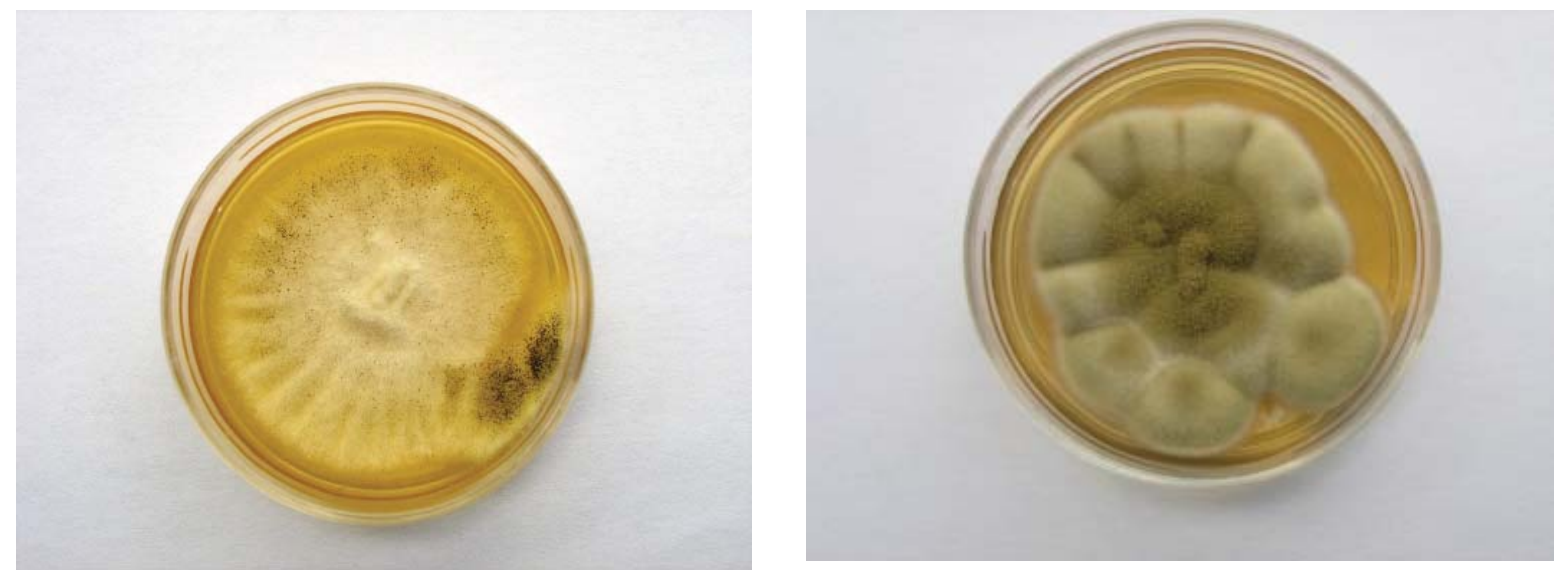

Fig. 1. Micromycetes isolated from tap water of the city Kiev, Aspergillus niger, Cladosporium cladosporioides

Such mushrooms go as transit through existing water treatment facilities and essentially influence on disease incidence of the population.

The high level of pollution of drinking water supply sources has forced to think about a cardinal problem: whether approach of GOST 2874-82 «Drinking Water» to determination of quality of drinking water is true. GOST 2874-82 provides, that safety of water for human health can be estimated under the additive scheme based on values of MAC of pollution of the same class of danger. Thus it is not taken into account influences of synergism effect of impurities on toxicity of water.

\section{Complex approach to the analysis of drinking water}

The method of water biotesting recently developed by the A.V. Dumansky Institute of Colloid and Water Chemistry of National Academy of Sciences of Ukraine (ICWC) has made it possible to approach the issue of determining the degree of drinking water toxicity based, in principle, on new approaches.

On the basis of long-term researches the complex approach to the analysis of drinking water is developed by methods of analytical chemistry, microbiology and biotesting which allow revealing a degree of influence of water impurity on human health. Thus, full physiological value of drinking water is also determined. According to modern criteria drinking water is considered qualitative if it does not contain toxic substances of any origin, and the content of 
impurities includes an optimum set of the elements necessary for maintenance of functional activity of a human body. Based on this, classification of quality of drinking water on a degree of its toxicity including three categories is offered: safe, not safe and hazardous. Thus, the following circumstances are taken into account. First, at an environment about 60000 substances are present, which besides are transformed. Second, various compounds show synergism effect in toxicity of water which in many cases is not investigated. Clearly, that, even possessing reliable techniques of analysis, it is practically impossible to determine the concentration of each of them in real terms.

Results of complex testing of surface water, underground waters, chlorinated tap water and the tap water purified with use of installations such as "Vega", are given in Table 1.

Comparative characteristic of quality of waters by results of complex testing

\begin{tabular}{|c|c|c|c|c|c|c|}
\hline No & Water origin & $\begin{array}{c}\text { Index of total } \\
\text { toxicity (ITT) }\end{array}$ & $\begin{array}{c}\text { Index of } \\
\text { cytotoxicity } \\
\text { (ICT) }\end{array}$ & $\begin{array}{c}\text { Index of } \\
\text { genotoxicity } \\
\text { (IGT) }\end{array}$ & $\begin{array}{c}\text { Cumulative Index } \\
\text { of toxicity (CIT) }\end{array}$ & Category \\
\hline 1. & $\begin{array}{c}\text { Surface waters } \\
\text { (Dnepr river) }\end{array}$ & 20 & 20 & 10 & 50 & Not safe \\
\hline 2. & Underground waters & 10 & 0 & 0 & 10 & Safe \\
\hline 3. & $\begin{array}{c}\text { Tap chlorinated water } \\
4 .\end{array}$ & 60 & 45 & 5 & 20 & Safe \\
& $\begin{array}{c}\text { Tap water after } \\
\text { treatment on "Vega" } \\
\text { installation }\end{array}$ & 10 & 5 & & 50 & \\
\hline
\end{tabular}

As follows from Table 1, chlorination of water results in a sharp increase of its toxicity. The underground (artesian) waters, sampled from 9 well-room type of wells of Kiev in which both, the cytotoxicity and genotoxicity are absent, are safe for human health. Treatment of toxic tap water at "Vega" type installation (fig. 2,3) secure its deep purification that is due to removal of extremely toxic chloro-organic compounds.

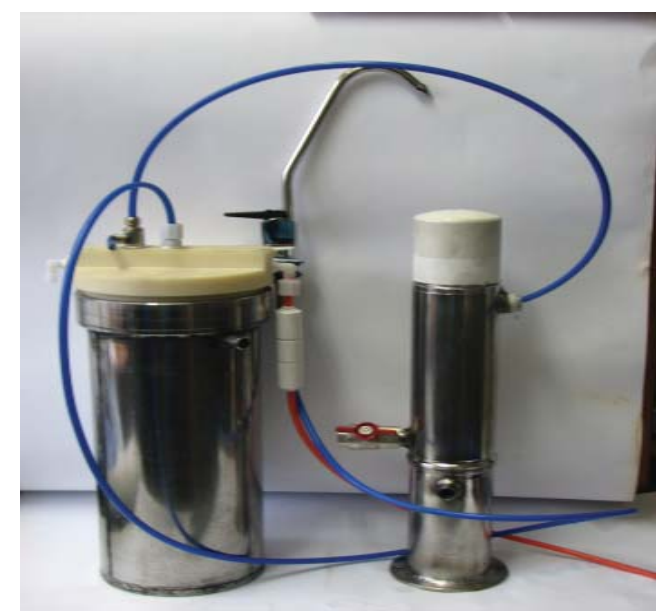

Fig.2. Installation "Vega" with productivity of 20 liters per hour

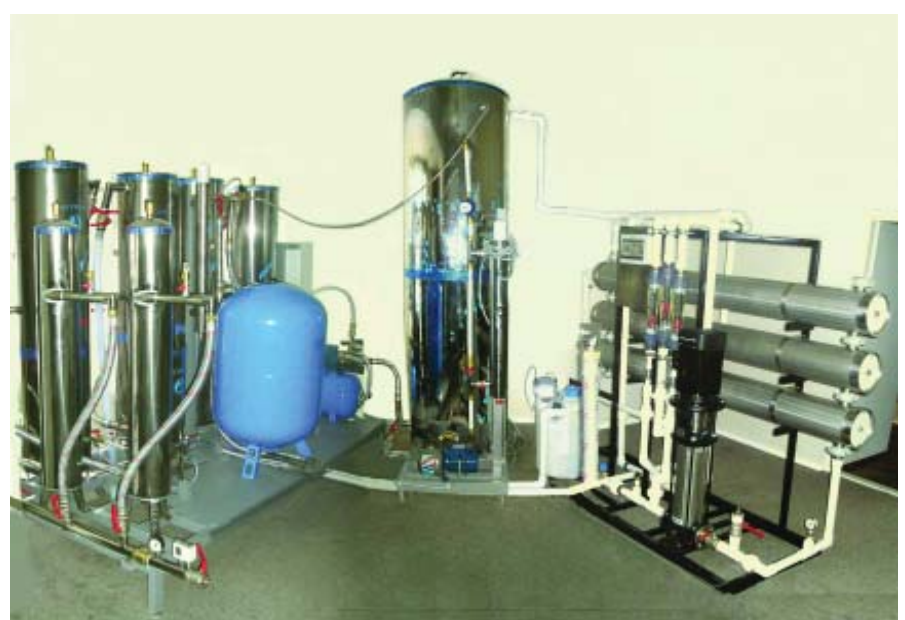

Fig.3. Multifunctional module installation "Vega-3UM" with productivity of 5000 liters per hour

Installations of such type have been developed, tested and successfully work in Kharkov, Barvinkovo (Kharkov region), Lviv, Yalta, Donetsk, Novoazovsk (Donetsk region), Mukachevo (Zakarpatye region), Pologi (Zaporozhye region) and in other sites.

It would seem that by packaging qualitative drinking water from the several reliably tested sources it is possible to solve a problem of supplying of the population with qualitative drinking water. However, the carried out researches have shown, that at storage and transportation of water its toxicity increased over time and the biomass development occurs especially at the temperature over $20^{\circ} \mathrm{C}$. Besides the toxicity of water can be caused by an addition of unsafe preserving agents at its packaging. It is confirmed by data of Table 2 , in which the data on quality of packed waters produced in Ukraine and Russia are given. 
Complex assessment of quality of the bottled waters on cyto-and genotoxicity parameters (2008)

\begin{tabular}{|c|c|c|c|c|}
\hline No & Brand of bottled water & $\begin{array}{c}\text { GP } \\
\text { (geno- } \\
\text { toxicity parameters } \\
\text { M \%o) }\end{array}$ & $\begin{array}{c}\text { GP } \\
\text { (geno - } \\
\text { toxicity parameters } \\
\text { 2N \%o) }\end{array}$ & $\begin{array}{l}\text { IC } \\
\text { (Index cyto- } \\
\text { toxicity) }\end{array}$ \\
\hline 1. & Morshynska & $\mathbf{0}$ & $\mathbf{0}$ & 2,21 \\
\hline 2. & Semeina & $\mathbf{0}$ & 0,33 & 2,65 \\
\hline 3 & Bonaqa* & $\mathbf{0}$ & 0,33 & 3,09 \\
\hline 4. & St.Mirgorod & $\mathbf{0}$ & 0,33 & 3,98 \\
\hline 5 & Arhyz* & 0,33 & 0 & 3,09 \\
\hline 6 & -Selen* & $\mathbf{0}$ & 0,66 & 3,94 \\
\hline 7 & Auqa minerale* & 0,33 & 0,33 & 3,98 \\
\hline 8 & Waterhall * & $\mathbf{0}$ & 0,99 & 5,70 \\
\hline 9 & Rokadovskaya & $\mathbf{0}$ & 0,66 & 7,52 \\
\hline 10. & Ordana & 0,33 & 1 & 10,33 \\
\hline 11. & Voda pytna & 0,66 & 0,99 & 10,48 \\
\hline 12. & Bebivita & 0,66 & 0,99 & 10,56 \\
\hline 13. & Vitel & 0,33 & 1,67 & 10,62 \\
\hline 14. & Hipp & 0,67 & 1,34 & 11,75 \\
\hline 15. & Demidovskaya* & 0,99 & 1,33 & 11,40 \\
\hline 16 & Pushkarskaya jivaya* & 0,99 & 1,33 & 11,84 \\
\hline 17. & Svyatoi istochnik* & 0,33 & 2,01 & 14,16 \\
\hline 18. & Sophiya Kiev & 0,99 & 1,33 & 16,11 \\
\hline 19. & Prozora & 0,33 & 2,01 & 16,14 \\
\hline 20 & Shishkin les* & 1,66 & 1,33 & 16,24 \\
\hline 21 & Senezskaya* & 0,99 & 2,34 & 16,23 \\
\hline 22. & Doktor & 1,67 & 2,34 & 18,14 \\
\hline 23 & Auqa-areal* & 1,67 & 2,67 & 20,61 \\
\hline 24. & Kalipso & 1,67 & 3 & 20,35 \\
\hline 25. & Humana & 1,67 & 3 & 20,35 \\
\hline 26. & Novoterskaya gornaya* & 1,67 & 3 & 23,25 \\
\hline 27. & SPA & 2,01 & 3,66 & 22,14 \\
\hline 28. & Znamenivskaya & 2,01 & 3,66 & 22,12 \\
\hline 29. & Piligrim* & 2,34 & 4 & 28,07 \\
\hline 30. & Contrex & 3 & 4 & 27,34 \\
\hline 31. & Gornaya vershina* & Test- organisms & died & \\
\hline
\end{tabular}

* - Water brands of Russia production.

1-4 - category "Safe water", meets to high quality drinking water;

5-19 - category "Not safe water", causes cytogenetic changes in cells of tests - organisms. It is undesirable for drinking use;

20-30 - category "Hazardous water", makes strong cyto-and genotoxicity action on tests - organisms. It is unsuitable for drinking use.

As follows from Table 2, only four trademarks of packed drinking waters, available in retail network, are safe for human health.

\section{Practical realization of the concept}

For practical realization of the concept, it is necessary:

- its approval at the state level and its adoption as a first-priority program of action in the field of population water supply;

- development and endorsement in the nearest future of new State Standards for tap, drinking, and bottled water;

- adoption of enactments, which would ensure unconditional fulfillment of State Standards in the field of population water supply by all entities of economic activity irrespective of ownership forms; 
- determination and implementation of first-priority and promising (for the nearest 5 years) of measures for the construction and equipment of water pump well rooms in Ukraine's regions.

Today, according to the aim to expand the realization of the new concept of supplying the population with qualitative drinking water, the Ministry of Housing and Municipal Economy of Ukraine together with A.V. Dumansky Institute of Colloid and Water Chemistry of National Academy of Sciences of Ukraine, have developed complex programs on introduction of installations of well-room type such as "Vega" in the Kherson, Sumy, Zhitomir regions, and in cities: Novograd-Volynsk and Borispol.

For operative quality assurance of the produced drinking water in ICWC has been developed the portable laboratory "Aqua-test " intended for the control of presence of the most widespread pollution of surface and underground waters (30 components) (fig. 4).

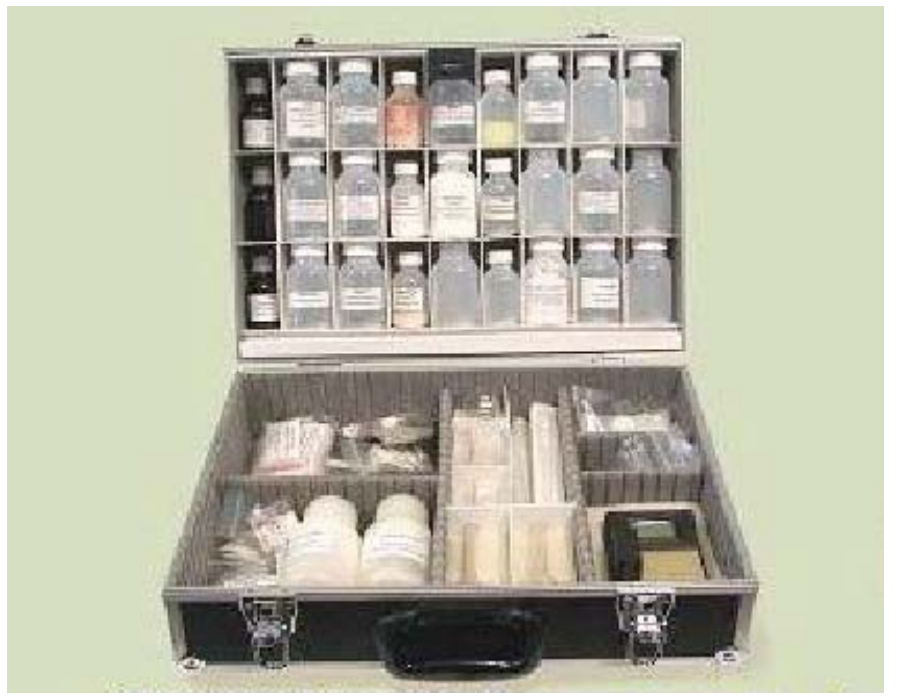

Fig. 4. Portable laboratory “Aqua-test” for monitoring water quality.

The principle of laboratory work rationally combines low cost and wide functionalities.

\section{References}

[1]. DSTU 4808:2007 Dzherela tsentralizovanogo pyntogo vodopostachannya. Gigienichni te ecologichni vymogy shchodoyakosti vody ipravyla vybyranny (Sources of Centralized Drinking Water Supply. Hygienic and Ecological Requirements to the Quality and Rules of Selection), Kiev: Derzhspozhyvstandart Ukrainy, 2007.

[2]. Goncharuk,V.V. Journal of Water Chemistry and Technology 2008, 30, 129-136.

[3]. Natsionalna dopovid' pro yakisf pytnoi vody ta stan pyntogo vodopostanchannya v Ukraini u 2005 rotsi [Electr. Resurs](The National Report on Quality of Drinking Water and the State of Water Supply in Ukraine in 2005 [Electr. Recourses], Kiev: Min. Bud-va, Architekt. ta Zhytl.-Komunal. Gos-va Ukrainy, 2006. http://www. min-jkg.gov.ua/index.php

[4]. Natsionalna dopovid' pro yakisf pytnoi vody ta stan pyntogo vodopostanchannya v Ukraini u 2006 rotsi [Electr. Resurs](The National Report on Quality of Drinking Water and the State of Water Dupply in Ukraine in 2006 [Electr. Resourse], Kiev: Min. Bud-va, Architekt. ta Zhytl-Komunal. Gos-va Ukrainy, 2006. http://www.minjkg. gov.ua/edi-tattach/bigdoc/nd_voda2006.doc.

[5]. Prokopov, V.A., Tarabarov, S.B., Teteneva, I.A., and Mironets, N.B., Sb. tez- nauch-prakt. konf. (Collection of Abstracts of (Collection of Abstracts of Scientific-Practical Conference Kiev, 1999), Kiev : 1999, 2, 1-5. 